\title{
Training in Education Management and the Performance of Head Teachers as Instructional Leaders
}

\author{
Rachel Mabuku Kabeta* \\ Zambia \\ *Corresponding Author: Rachel Mabuku Kabeta, Zambia

\begin{abstract}
The National Education Policy of Zambia states that effectiveness in the delivery of education depends on the quality of school administration. The policy further states that school heads need training in educational management and supervision in order to be effective. However, the policy acknowledges that the majority of those occupying supervisory and management positions have not received relevant training for their positions. Teachers are appointed straight from classrooms to management positions without prior training in management and leadership. This paper presents perspectives of Head teachers and teachers on the aspect of training for teachers appointed into leadership positions and the challenges in the efforts to offer such training by the Ministry of Education. The perspectives are obtained through a study of 32 head teachers and 160 teachers in selected schools in the Central Province of Zambia. The results show that the majority of the head teachers who participated in the study did not receive training that prepared them for their role. The findings reveal further that the Zambian Education System does not have much provision for training of head teachers in educational management and as a result such training is not a prerequisite to being appointed as a head teacher. This has a negative impact on the performance of the head teachers and affects student academic performance.
\end{abstract}

Keywords: Instructional leadership, Management, Head teachers, teachers, Perspectives, Training, Student academic performance

\section{INTRODUCTION}

Research shows that one of the factors that can influence the quality of teaching and learning in schools is the nature of leadership. Harries et al (2003) indicates that the most important single factor in the success of the school is the quality of the leadership of the head.Fullan (2001) also supports this when he states that increasingly, research has been associating school leadership with the quality of learning and teaching and the motivation of teachers and the ethos of the school. The Ministry of General Education in Zambia Policy document "Educating Our Future" (1996) identifies the vital role that the school head must play in pursuit of excellence and quality of education. The policy further acknowledges instructional leadership by head teachers as a priority in enhancing the teaching and learning in schools. The policy also acknowledges the importance of training for school leaders in educational management and leadership if they have to be effective instructional leaders.

\subsection{Statement of the Problem}

The National Policy on Education in Zambia of 1996 'Educating Our Future' states that effectiveness in the delivery of education depends heavily on the quality of educational administration and that school heads, education officers and inspectors need training in educational management and supervision. However, the policy further acknowledges lack of relevant and adequate training for head teachers prior to their appointment. Therefore, a study focusing on this area would bring about awareness of the importance of relevant training in educational management and leadership if head teachers need to be effective instructional leaders.

\subsection{Purpose}

The purpose was to establish whether head teachers in the basic schools in the Central Province of Zambia received any relevant training preparing them for their role. 


\subsection{Research Objective}

To establish whether the head teachers received any relevant training that prepared them for their role and the effect on their performance as instructional leaders.

\subsection{Research Question}

What is the effect of training in educational management and leadership on the role of head teachers as instructional leaders?

\subsection{Theoretical Framework}

Many researchers define instructional leadership through the traits, behaviours and processes a person needs to lead a school effectively. This study was guided by various leadership theories such as the trait, behavior, contingency, charismatic and transformational leadership. The trait theory identifies trait variables associated with effective leadership. Hoy and Miskel (2000) have categorized these traits into personality, motivation and skills. Personality traits consist of personal characteristics that are inherent to an individual's actions and demeanor such as self-confidence, integrity, energy, stress tolerance and emotional maturity. Motivation traits include a person's level of expectations, power, drive, and intensity. Skills associated with effective leadership encompass relevant task knowledge and skills needed to accomplish goals and objectives set forth by an organization. Mullins (2007) indicated that behavioral approach draws attention to the kinds of behavior of leadership situations and centered on interpersonal relations or consideration for others and task oriented behaviors such as goal attainment, production and structure. (Hoy and Miskel, 2000).Burns (1978) defines transformational leadership as a process in which leaders and followers raise one another to higher levels of morality and motivation. The followers feel trust, admiration, loyalty and respect toward the leader, and they are motivated to do more than they originally expected to do.

These leadership theories exemplify the premise of instructional leadership and show how a head teacher can utilize the characteristics of the various theories and become an effective instructional leader. Instructional leadership combines many of these theories and puts them into practice. Effective instructional leaders possess specific traits and behaviors such as charisma, energy, drive which may be applied in different situations and environments.

This is exemplified in the diagram below:

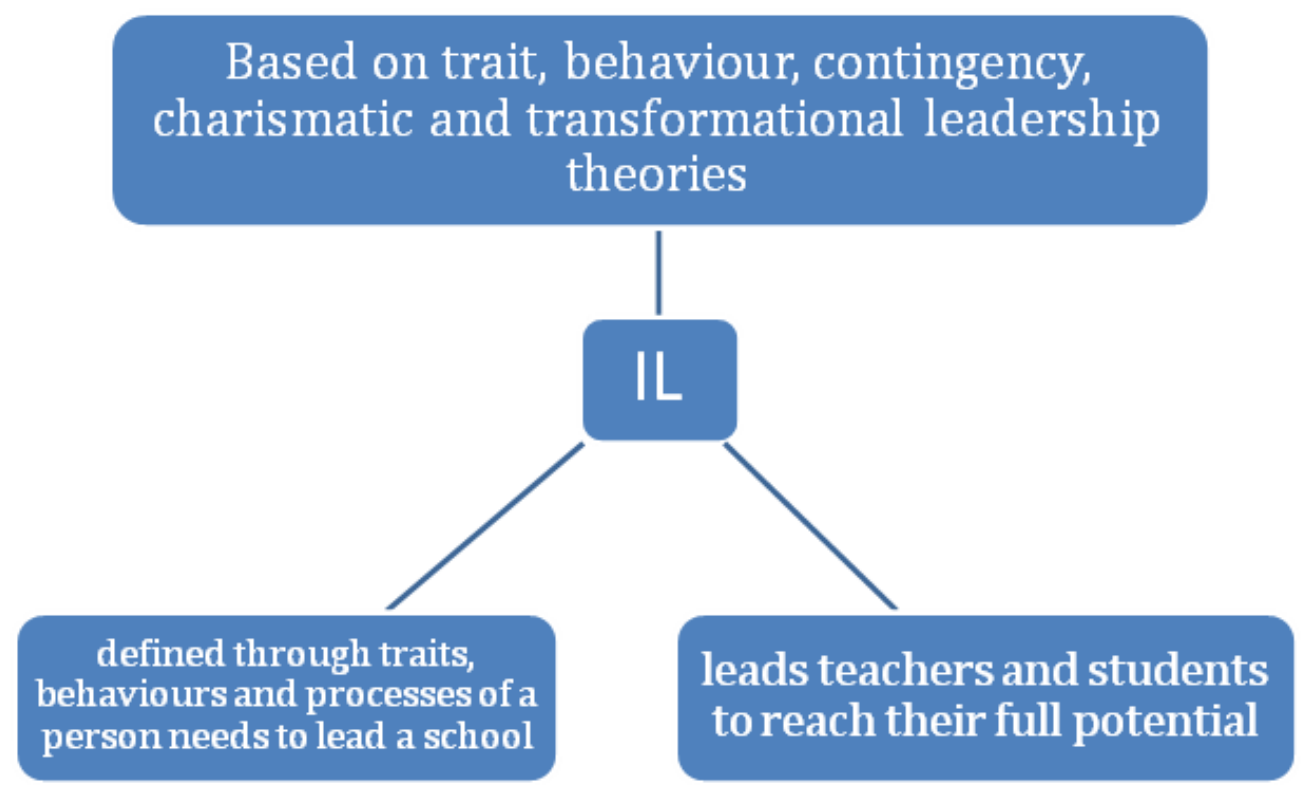

Figure1. Leadership Theory: an overview of Instructional Leadership (Source: Author)

The premise of instructional leadership is to lead teachers and students to reach their full potential by creating conducive learning environments, defining and communicating shared goals, monitoring the teaching and learning process and providing continuous development to teachers and other stake holders. 


\subsection{Significance of the Study}

The findings of this study therefore might be useful to Ministry of General Education policy makers to understand the importance of training teachers and head teachers in Educational Management and Leadership. Further that such training should be used as a pre requisite for the appointment to positions of school leadership. The findings of this research may help to refine and expand the training programmes for teachers such that components like instructional leadership could be incorporated in the course programmes.

\section{LITERATURE REVIEW}

Chapman (2000) points out that the major reason for the deficiencies among school leaders is that training whether pre service or in service is often unavailable, inadequate, or inappropriate. Lockheed and Veerspoor (1991) further state that additionally, opportunities and incentives for advancement, clearly defined career paths, and systems for assessing performance are absent and further state that the lack of such inputs not only hinders the professional development of school leaders but also dampen their motivation to perform well. Many researchers cited in Sandhvid (2009) argue that school principal training before appointment is virtually non-existent among developing countries except for the on-job-training for a teacher who has served as a deputy or assistant principal.

These researchers further state that studies in Egypt, Indonesia and Paraguay have found that a principal's teaching experience and instructional leadership training are related to higher student achievement. Lockheed and Veerspoor(1991) go on to state that only a handful of developing countries such as China, Ethiopia, Kenya, Malaysia, Papua New Guinea, the Phillipines and Thailand, have addressed the need to improve school management, primarily by establishing institutions to train school principals.

Chapman (2000) observes:

.......even if education managers have strategic planning skills, they often lack a firm understanding of the educational process. They do not know what inputs and processes can reasonably be expected to contribute to increased student learning. Lacking this, managers are left to retract to daily events and political pressures. One implication is that managerial training needs to provide education managers with some framework for understanding the educational process and information on interventions that have the best chance of yielding promising outputs, (p.304).

\subsection{Head Teachers' Training in Zambia}

The situation in Zambia regarding the training of head teachers is not any different from what has been discussed above. The National Policy on Education in Zambia of 1996 'Educating Our Future' states that effectiveness in the delivery of education depends heavily on the quality of educational administration and that school heads, education officers and inspectors need training in educational management and supervision. However, the policy further acknowledges lack of relevant and adequate training for head teachers prior to their appointments. Most of the head teachers are usually promoted to their positions on the basis of long service and age, and in such cases classroom performance is not even considered.

According to Maliwatu (2011) the current trend in Zambia in most cases is that teachers are promoted and then trained later, there is likelihood that before the head teachers are trained, they will be using trial and error approach in doing their work. The policy also noted that the state of affairs where the majority of those occupying supervisory and management positions not having received the relevant training has led to inefficiencies and poor performance in the management and supervision of the education system.Bhagwan and Bhushan (2006) noted that learning by trial and error has its pitfalls; it may impair efficiency of administration, and that a lot of risk is involved in expecting the employee to learn by trial and error.

The education system in Zambia does not take training in educational management into account when promoting teachers to become head teachers. As stated earlier, the majority of those heading schools have no training in educational management, their promotion and appointments are usually based on their successful classroom performance, age or length of service.

Mebrahtu et al cited in Mwanza (2004) supported this when he stated that, 
In Zambia, as indeed elsewhere in Africa, the overwhelming majority of inspectors, school heads, and educational officers in the field have never had either pre-service or in-service training in educational management prior to their appointment. (1996: 5).

The National Policy document, "Educating Our Future", (1996) acknowledges the need to train the people occupying supervisory and management positions in the education sector.

This is supported by sarason cited in Fullan (1991) when he observes that being a classroom teacher by itself is not a very good preparation of being an effective school head.

Lungwangwa et al (1995) states that management of education is an issue that has increasingly attracted the attention of policy makers and researchers in recent times and that one way of ensuring that there is effective management of education is the provision of continuous and relevant training.

The Ministry of Education has been making efforts to support head teachers to improve their skills in order to improve school effectiveness. This effort is in line with the National Policy Document on Education- Educating Our Future (1996) statement that "the prevailing situation in most schools is far from the Ministry of Education's expectation of excellence because of the way schools are being run. The policy document identifies educational management training programmes for head teachers and deputy head teachers as a priority for making schools effective and raising the standards of education in Zambia.

A review of literature regarding training of school leaders in other countries revealed that, people aspiring to be school leaders are required to take training in educational management and leadership. According to Alkin (1992), in countries like United States of America, there are various programmes that are designed to prepare people for various administrative positions such as heads of departments, assistant principals and principals.

\section{MeTHOdOLOGY}

\subsection{Research Design}

The study from which this paper is drawn employed both qualitative and quantitative approaches. The quantitative data was obtained through the Principal Instructional Management Rating Scale (PIMRSPrincipal and Teacher forms) by Hallinger (1995); while qualitative data was collected through faceto-face interviews, focus group discussions, observations and document analysis. This paper only presents the qualitative data obtained through the face-to-face interviews and focus group discussions.

\subsection{Research Sample}

The study sample comprised 32 head teachers and 160 teachers who were selected using purposive sampling.

\subsection{Research Instruments, Data Collection Procedures and Data Analysis}

The quantitative data obtained through the administration of the PIMRS was analyzed using the Statistical Package for Social Sciences (SPSS), statistical analysis software. Combined responses from head teachers and teachers were also calculated. To analyze the qualitative data obtained some of the six typical phases for analysis in qualitative research described as: organizing the data; generating categories, themes, and patterns; coding the data; testing the emergent themes; searching for alternative explanations; and writing the report Patton,( 2004) were used.

\subsection{Ethical Considerations}

Ethical considerations were taken into account such as seeking permission from relevant authorities from the Ministry of Education and Provincial Education Offices and taking into consideration issues of respondent's confidentiality and other basic research conventions.

\section{FINDINGS AND DISCUSSION}

It was established from the responses obtained through the head teachers and teachers that the majority of head teachers who participated in this study did not receive relevant training in educational management prior to their appointment as head teachers.

Out of the 32 head teachers only 5 head teachers had attended the Education leadership and Management Course that was offered at NISTCOL, representing about $16 \%$.The responses further 
revealed that the head teachers only did some components in education management in their preservice courses. The head teachers who had attended the training at NISTCOL said that they did things differently and further stated that at least they were familiar with aspects of leadership and how to manage a school.

\subsection{Head Teachers}

The responses of head teachers revealed and confirmed what the National Policy on Education states that head teachers in Zambia are appointed based on their seniority in the ministry and do not receive relevant training and as a result they lead and manage their schools based on trial and error. It was also revealed that most of the head teachers depended on the experience they gained from working under what they called "experienced head teachers". A head teacher echoed this in this response:

The Ministry of Education structures do not offer specific training for head teachers; we basically learn from our previous supervisors. People will just look at how you were practicing in your previous position and if they are satisfied that you have what it takes, that's what they consider.

Another head teacher admitted that that he did not receive any training because of limited openings to do the Education Management Course at NISTCOL and had this to say:

I have not done any training because at that time there were limited openings at the National In-Service College (NISTCOL) for one to do the Educational Management Course (EMT), but it is very important to train because what we are doing now is job on training, trial and error and sometimes you make a lot of mistakes, you need guiding rules to help you move forward, because sometimes even a teacher you are managing can have more knowledge than you and can control you and then you have conflicts.

The head teachers agreed that training in educational leadership and management was very important in the role of a head teacher. They said that there should be a course or training specifically tailored to prepare teachers for the leadership role in schools and that the appointments of head teachers should be based on relevant training.

This was echoed by a head teacher who added that:

The initial training as a teacher is not enough to prepare teachers for the role of head teachers and the challenges that go with it because it only scratches on the basics and never goes into detail thus the need for further training.

Another head teacher added:

The Ministry of Education, does not offer further training to teachers when they appoint them as senior teachers or head teachers, there is no course which they undergo; there are only orientation workshops which are not enough. When one is subjected to a training curriculum, I want to believe that, that the very curriculum should be tailored in such a way that those gaps are reduced so training still remains a very important component.

The head teachers who had the opportunity to attend training after being appointed head teachers supported the idea of training saying that it gave them an idea of where to start from as a head teacher and enabled them to do their work without too many difficulties.

One head teacher who had attended the Education Leadership and Management Course acknowledged the relevance of the training she received:

Just after being appointed head teacher, I was offered an opportunity to attend the Education Leadership and Management Course that is being offered by the National in Service Teachers College; the course was very helpful, without the course you can do things haphazardly. The course is all about managing the school; what you learn there is what you do in the school.

The head teachers further added that as a result of the training, they do a lot of things differently. They said that in their training they learned about; monitoring and evaluation, tracking and analyzing pupils' results, learned about delegation and school-community partnerships.

Another head teacher stated:

I was nominated to go and do the Education Management and Leadership course and we learned a lot of things such as managing resources especially finances, record keeping, 
budgeting and managing people and we also learned about instructional leadership though not in much detail as the questionnaire showed, and the duration too for the course was not much but am happy I did the course.

\subsection{Teachers}

The teachers equally indicated the importance of training and said that the opportunities for training teachers for leadership positions should be expanded so that all the teachers are trained. They added that this will avail the Ministry of Education with a wider pool of trained teachers from where they could appoint head teachers and other educational leaders. All the teachers interviewed supported the idea of teachers receiving adequate training prior or after being appointed as head teachers. They reiterated what the head teachers stated about the pre-service training they received:

You know the pre-service training we receive as teachers does not offer much in leadership training, some courses we did especially at diploma level did not offer enough content in management training, there is need to have more institutions that will be training teachers in management and leadership courses.

\section{Summary OF KeY Findings, CONCLUSIONS AND IMPLiCATIONS}

What lessons can we take from the perspectives of head teachers and teachers on the effect of training in educational management and leadership on the performance of head teachers?

The findings of this study show the effect of lack of training in educational management and leadership on performance of head teachers. The findings show that the education system in Zambia does not have much provision for training head teachers in education management and leadership. The findings further revealed that most of the head teachers did not receive training prior to their appointment and therefore depended on the experience of working under what they referred to as "experienced head teachers" and also that there was a lot of trial and error in doing their work. The findings further show that it is not only head teachers who do not have prior training in management but also the educational inspectors and education officers in the field have never had either pre-service or in-service training in education management. The findings also show that the head teachers are appointed based on their seniority, age and lengthy of service.

The findings further reveal that all the head teachers who participated in this study agreed that training would enhance their leadership practices. The five head teachers who had taken training said that they did things differently and this was evidenced through the observations by the researcher. Bhagwan and Bushan (2006)State that no matter how well grounded an employee may be in the general subject to which his work relates, there was need for him to learn in respect to the particular duties of his position. Literature regarding the training of school leaders in developed countries such as the USA as cited in Maliwatu (2011) showed that people who were aspiring to be school leaders were required to take training in educational leadership and management and that there were various programmes that were designed to prepare people who included heads of department, assistant principals and principals for various administrative positions.

It is clear from the findings of this study that very few head teachers in Zambia receive training to prepare them for their role and that the opportunities for such training were limited. It is also evident that the Zambian Education system does not have specific institutions that offer preparatory roles for leadership positions and that even where there were a few opportunities, the training was usually concentrated more on managerial than instructional components.

The findings of this study clearly show the need for the review of the training opportunities that are available and the need for the scope to be broadened to include leadership aspects such as instructional leadership.The findings further reveal that the majority of the head teachers who participated in this study did not receive training because the openings in the Education Management and Leadership Course at the National In-service College which was the major institution that was offering in-service training to head teachers in Zambia were limited. While research asserts the need for training for school leaders if they have to be instructional leaders, the findings in this study show that very few head teachers got the opportunity to be trained in Education administration and leadership.

It is clear from the findings of this study and from literature that there is a relationship between training and the level of instructional leadership that a head teacher exercises. Inadequate training in 
education management and leadership or lack of it negatively affects the levels of instructional leadership. The findings of this study conform to what is stated in literature that most head teachers in developing countries were usually appointed to their positions of school leadership with inadequate training or without any training at all that prepared them for this role. As a result the head teachers performed their duties using trial and error. Bhagwan and Bhushan (2006) assert that learning by trial and error has its pitfalls and may impair efficiency of administration.

One of the major obstacles to head teachers in this study practicing instructional leadership was lack of in- depth training for head teachers in educational leadership and management. This has led to head teachers having very little or no knowledge of instructional leadership leading to more concentration on managerial duties at the expense of instructional leadership. Clearly, this has led to the poor performance in their schools because the core business of teaching and learning is taken as a by the way function.

By deduction, there is need for the head teachers to shift from being managers to instructional leaders if performance of teachers and pupils has to improve. Hallinger (2012) states that preparation as a teacher neither ensures that a prospective principal is capable of leading others nor that they have the specific expertise in curriculum and instruction. University based programmes have not generally developed these capacities in depth required for principals to engage in teachers productively in changing their teaching practice, and thus upon assuming their administrative roles, many principals lack the expertise and confidence to focus on this part of the job. This leads to head teachers shunning the instruction role for fear of being embarrassed by a teacher who may be more knowledgeable.

\section{CONCLUSiON}

The study concluded that there was a positive linkage between training in education management and the performance of head teachers as effective instructional leaders. Further that the head teachers who participated in this study did not receive relevant training that prepared them for their role as head teachers and they were performing most of their duties using trial and error. The study also concluded that the Ministry of Education did not take training in education management as a pre requisite for one to be appointed as a head teacher.

\section{RECOMMENDATION}

The Ministry of Education should strengthen and expand the training programmes in Education Management for teachers and head teachers. Further create institutions that will specifically offer preparatory school leadership training to teachers who aspire to become head teachers as it was the case in countries like the United States of America, Canada and some developing countries which higher levels of instructional leadership. Training in education management should be considered as a pre requisite for one to be appointed as a school leader.

\section{REFERENCES}

[1] Alig-Mielcarek, J, (2003), A Model of Success: Instructional Leadership, Academic Press and Student Achievement, Dissertation.

[2] Alkin, M.C, (1992), Encyclopedia of Educational Research, New York: Macmillan

[3] Atkin, L, \& Wallace, S, (2012), Qualitative Research in Education, SAGE Publications

[4] Bhagwan, V,\& Bhushan, V, (2006), Public Administration, New Delhi: S. Chand and Company, Ltd.

[5] Barker, B, (2007), The Leadership Paradox: Can School Leaders transform student Outcomes? School effectiveness and School Improvement 18, No.1: 21-43

[6] Burns, J.M. (1978), Educational Leadership: Staff Development. Cape Town: Nassou

[7] Chapman, D, (2000), Trends in Educational Administration in Developing Asia, Educational Administration Quarterly, April 2000 Vol. 36 No.2 pp.283-308

[8] Hallinger, P, (2012), A Data Driven Approach to Assess and Develop Instructional Leadership with the PIMRS. Hong Kong Institute of Education

[9] Harris, A, (2003), Improving Ineffective Departments in Secondary Schools: Strategies for Change and Development, Educational Management and Administration, 26 (3), 269-278

[10] Hoy, A. \& Hoy, W, (2003), Instructional Leadership: A Learning Centre Guide, Boston MA: Allyn $\&$ Bacon

[11] Hoy, W\&Miskel, C, (2000), Educational Administration: Theory, Research and Practice. $6^{\text {th }}$ Ed. New York: McGraw Hill. 
[12] Fullan, M, (2001), Leading in a Culture of Change; San Franscisco, CA: Jossey-Bass Inc.

[13] Fullan, M, (2008), what is Worth Fighting for in the Principalship? London: Cassell.

[14] Fullan, M, (1991), The New Meaning of Educational Channge. London: Cassell.

[15] Lockheed, M.E \&Verspoor, A.M. (1991), Improving Primary Education in Developing Countries. Washington, DC; World Bank

[16] Lungwangwa,G et al (1995), The Organization and Management of Education in Zambia.

[17] Maliwatu, J. (2011), In Service Training for Head teachers and its Effect on their Leadership Practices. Lusaka, Zambia.

[18] Mullins, I.J, (2007), Management and Organizational Behaviour, $8^{\text {th }}$ Edition. Pearson; Prentice Hall

[19] Mwanza, P, (2004), Teacher Perceptions of School Management Practices and their influence on Teacher Performance in Selected High Schools of Lusaka.

[20] Ministry of Education, (1996), Educating Our Future; Zambia National Publishing House

[21] Ministry of Education, (2007), Educational Statistical Bulletin, Lusaka

[22] Ministry of Education, (2009), Baseline Study on Education Management Course; Nistcol: Zambia

[23] Patton, M,Q, (2002), Qualitative Research and Evaluation Methods; Thousand Oaks: Sage New Delhi

Citation: Rachel Mabuku Kabeta. "Training in Education Management and the Performance of Head Teachers as Instructional Leaders". International Journal of Humanities Social Sciences and Education (IJHSSE), vol. 6, no.8, 2019, pp. 14-21. doi: http://dx.doi.org/10.20431/2349-0381.0608002.

Copyright: () 2019 Authors. This is an open-access article distributed under the terms of the Creative Commons Attribution License, which permits unrestricted use, distribution, and reproduction in any medium, provided the original author and source are credited. 